\title{
Geochemistry and Detrital Modes of Sandstone From Barakar Formation in Mand Valley Basin, Chhattisgarh, India: Implications for Provenance, Tectonic Setting and Paleoweathering
}

\author{
Afreen Noori *, Sarwar Rais \\ Department of Geology, Aligarh Muslim University, Aligarh, India \\ *Corresponding author E-mail: afreen.n.khan@gmail.com
}

Copyright (C) 2014 Afreen Noori, Sarwar Rais. This is an open access article distributed under the Creative Commons Attribution License, which permits unrestricted use, distribution, and reproduction in any medium, provided the original work is properly cited.

\begin{abstract}
Geochemistry and petrographic analysis of sandstones of the Lower Permian Barakar Formation (Lower Gondwana) Mand valley basin, Chhattisgarh, India have been undertaken to interpret their provenance, tectonic setting, paleoweathering and climatic conditions. The petrology of these Barakar sandstones reveal that they are mainly composed of variable amounts of monocrystalline and polycrystalline quartz, potash and plagioclase feldspars with minor amount of micas and chert as well as metamorphic and sedimentary rock fragments in addition to heavy accessories. Based on the modal analysis, the Barakar sandstones are classified as subarkose and sublitharenite types. Plots of sandstone composition in tectonic setting discrimination diagrams suggest derivation of these detritus from craton interior and recycled orogenic provenance. Tectonic setting discrimination diagrams based on major elements composition suggest a quartzose sedimentary provenance in a passive continental margin. Chemical Index of Alteration (CIA), Chemical Index of Weathering (CIW), Plagioclase Index of Alteration (PIA) indices and A-CN-K plot suggest moderate to intense weathering of source rocks under humid climatic condition.
\end{abstract}

Keywords: Barakar Sandstone, Geochemistry, Mand Valley Basin, Provenance, Tectonic Setting.

\section{Introduction}

Modal analysis of sandstones has been widely used to decipher the provenance and its tectonic setting [1- 4]. Because weathering and diagenetic processes can modify the original component derived from source area, therefore, provenance characterizations, only on the basis of petrological studies have some limitations. Geochemical investigation of the sandstone can help to overcome these shortcomings of compositional study. So combination of petrographic and geochemical data of sedimentary rocks can provide a more comprehensive picture of provenance, tectonic setting, paleoclimate and intensity of the weathering. Present investigations therefore, examines the detrital components and geochemistry of the Barakar sandstone (Lower Permian) of Mand valley basin, Raigarh district, Chhattisgarh, India to constrain the nature and tectonic setting of the provenance, paleoweathering and paleoclimatic conditions of the sedimentation.

\section{Geology}

The Gondwana strata of peninsular India occur along three major river valleys as linear belts. These major basins are Koel-Damodar, Son-Mahanadi and Pranhita-Godavari along with some isolated basins (Fig. 1 A). All these basins are intracratonic in nature. Deposition in these basins commenced from Upper Carboniferous and continued up to upper Cretaceous [5]. The Gondwana sequence starts with glaciogenic clastics at the base, followed by glacio-lacustrine/ fluvial and fluviatile deposits. The Gondwana sediments lie over the Precambrian crystalline basement. The contact is 
demarcated by either an unconformity or in some basins by marginal faults [6]. The study area lies within MandRaigarh basin (Fig. 1 B), which is the north-westerly continuity of the Ib river coalfield of Odisha. Both of these are sub-basins of the Son-Mahanadi master basin. The Mand valley basin is located in the eastern part of Son-Mahanadi basin and stretches from $21^{\circ} 45^{\prime}$ to $22^{\circ} 42^{\prime} \mathrm{N}$ and $83^{\circ} 01^{\prime}$ to $83^{\circ} 44^{\prime} \mathrm{E}$ covering an area of about $900 \mathrm{sq} \mathrm{km}$. in the Raigarh district of Chhattisgarh, India. Raja Rao [7] surveyed Mand basin and proposed stratigraphic succession (Table 1).

Table 1: Modified General Stratigraphic Succession of Mand Valley Basin after Raja Rao [7].

\begin{tabular}{|c|c|c|c|}
\hline Age & & Formation & Lithology \\
\hline $\begin{array}{l}\text { Cretaceous to } \\
\text { Eocene }\end{array}$ & & Deccan trap & Basalt flows and dolerite dykes \\
\hline Lower Permian & 胥 & $\begin{array}{l}\text { Kamthi } \\
\text { Formation }\end{array}$ & $\begin{array}{l}\text { Variegated sandstone with lenses } \\
\text { of clay, arenaceous shales, clay } \\
\text { beds, carbonaceous shales and } \\
\text { coal seams }\end{array}$ \\
\hline & 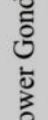 & $\begin{array}{l}\text { Barakar } \\
\text { Formation }\end{array}$ & $\begin{array}{l}\text { Coarse to medium grained } \\
\text { sandstone, grits, grey shales and } \\
\text { coal seams. }\end{array}$ \\
\hline $\begin{array}{l}\text { Upper } \\
\text { Carboniferous (?) }\end{array}$ & 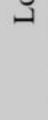 & $\begin{array}{l}\text { Talchir } \\
\text { Formation }\end{array}$ & $\begin{array}{l}\text { Diamictite, fine to medium } \\
\text { grained sandstones, olive green } \\
\text { shale, rhythmites and turbidites. }\end{array}$ \\
\hline Precambrian & & \multicolumn{2}{|c|}{ Crystalline Rocks } \\
\hline
\end{tabular}

The entire Mand valley basin is characterized by Talchir Formation at the base with diamictite, sandstone and shale, directly followed by Barakar Formation, and overlain by Kamthi Formation. In the investigated area the Barakar Formation conformably overlies the Talchir Formation, which is the basal member of Gondwana strata. The Barakar Formation comprises of cyclic sequence of sandstone, shale, carbonaceous shale and coal seams in this area.
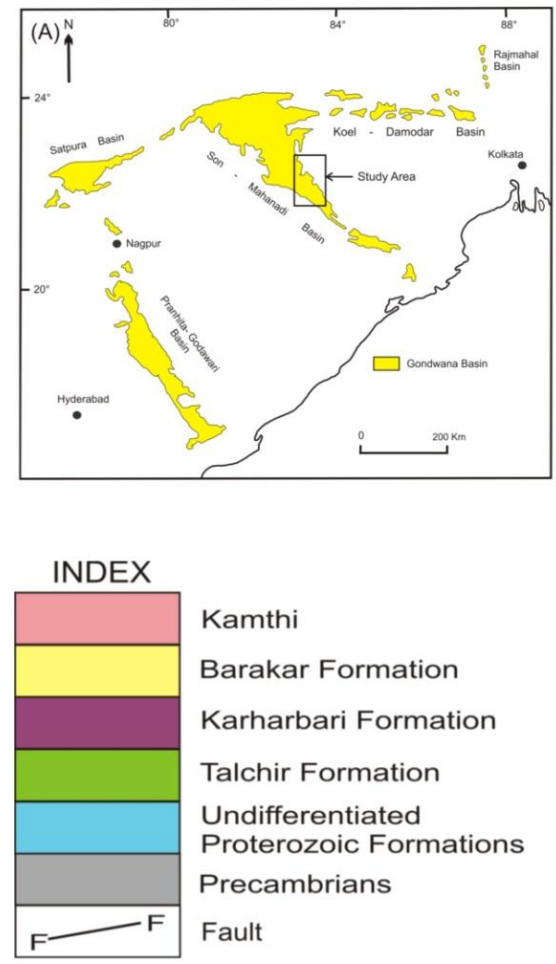

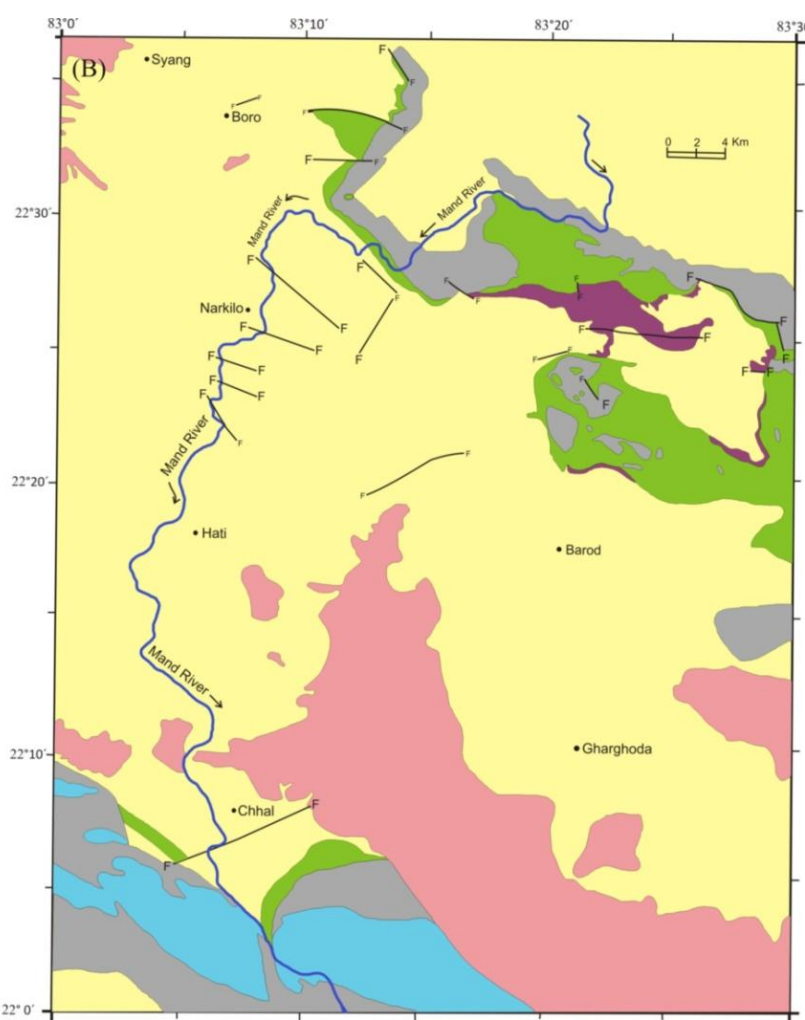

Fig. 1 (A): Distribution of Gondwana basins in peninsular India and; (B) Generalized Geological Map of Mand valley basin, Chhattisgarh, India after Raja Rao [7] 


\section{Methodology}

An integrated petrographic and geochemical study of the Barakar sandstones (Lower Permian) of Mand valley area Raigarh district, Chhattisgarh has been carried out. Fresh sandstone samples from the Barakar Formation were selected and thin sections were prepared. Thirty representative sandstone specimens of Barakar Formation were selected for detailed petrographic study using standard techniques. Mineralogical composition of the sandstones was determined by Gazzi- Dickinson point counting method [8-9] and 400-500 grains were counted in each thin section. Framework parameters following Dickinson and Suczek [1]; Dickinson et al. [2]; Dickinson [3]; Folk, [10]; Suttner et al. [11]; Suttner and Dutta [12] are adopted in the present investigation and are presented in Table 2. Recalculated modal analysis data, from point counting of the framework grains of Barakar sandstones, are listed in Table 3. Provenance discriminations are based on the schemes of Dickinson et al. [2] and Dickinson [3]. Different triangular diagram plots of detrital composition are used to infer provenance, tectonic setting and paleoclimate reconstruction.

X-ray fluorescence (XRF) analysis for major oxides of Barakar sandstone samples was conducted at National Institute of Oceanography, Goa, India. Out of thirty, twelve representative Barakar sandstone samples were subjected for major oxides analysis. These sandstone samples were reduced to small sized rock chips using mortar. Using a tungsten carbide mill these rock chips were powdered to $\sim 200$ mesh size. Whole rock major oxides compositions of sandstone were carried out using pressed pellets on the AXIOS, PANanalytical X-ray Fluorescence (XRF) spectrometer.

Table 2: Framework Parameters Used In this Study [after 1, 2, 3, 10, 11, and 12].

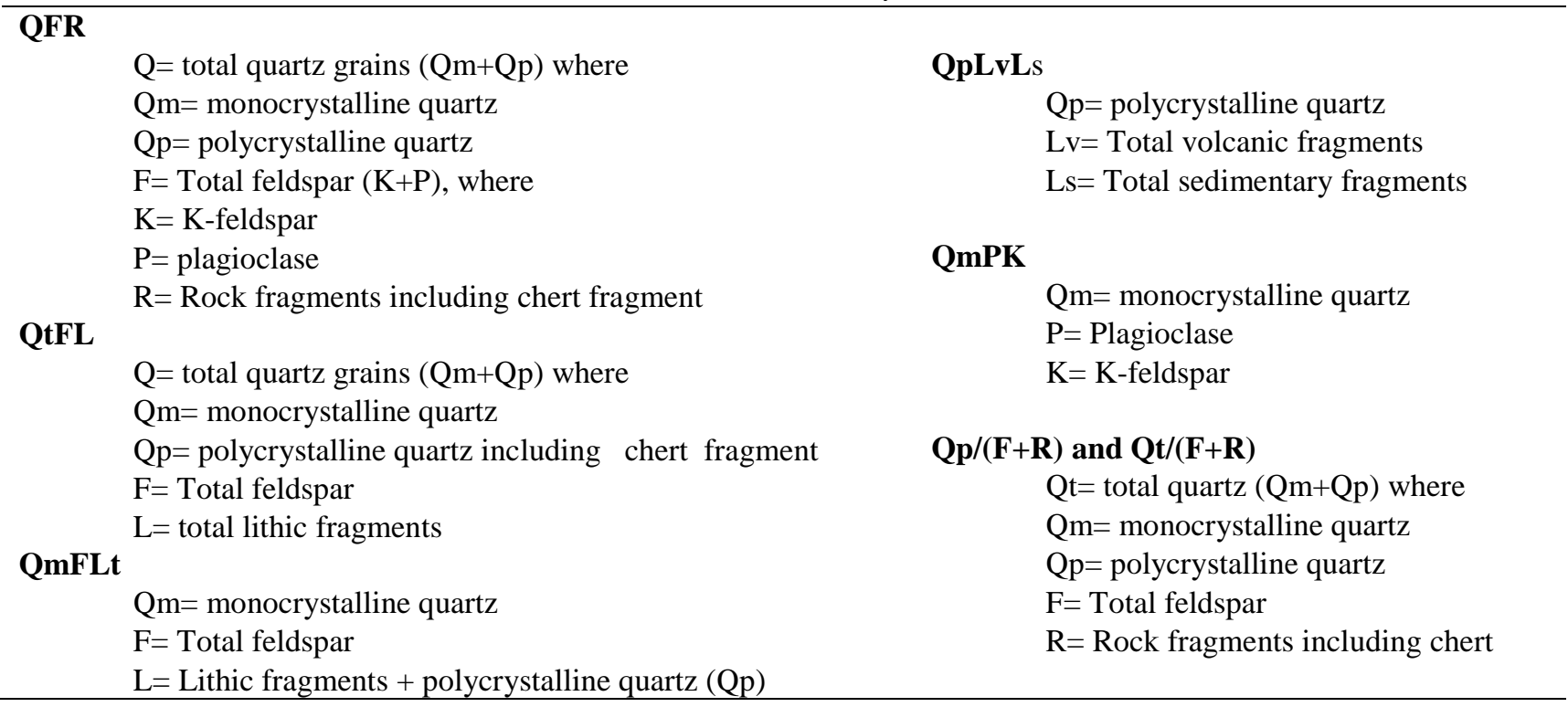

\section{Results}

\subsection{Petrography}

Petrography of sedimentary rocks helps in understanding the geological history by providing clues about the source rock, environment of deposition, diagenetic history and tectonic setup of the provenance. The analyzed sandstone samples of the Barakar Formation from Mand valley basin are very coarse to coarse and medium grained, moderately to well sort. The framework grains of these sandstones are composed of monocrystalline quartz (Qm), polycrystalline quartz (Qp), K-feldspar, plagioclase, rock fragments, micas and heavy minerals. Quartz is the most dominant constituent of the studied Barakar sandstones. Mono-crystalline quartz $(\leq 75.45 \%)$ is more abundant than polycrystalline quartz $(\leq 37.16 \%)$. The feldspars $(\leq 15.16 \%)$ are represented by orthoclase and twinned microcline with few plagioclase grains. Sedimentary and metamorphic lithic fragments occur in variable proportions. Sedimentary lithic fragments are the major rock fragments. Chert grains are also seen in some sandstone samples. Micas have been noted in the form of muscovite laths and biotite flakes. All studied samples contains minor amount of accessory minerals comprising of garnet, tourmaline, zircon, and opaques. These sandstones have iron, carbonate and silica cements. Some of these samples also have minor amounts of clayey matrix. Recalculated framework composition is used for classification of these sandstones after Folk [10]. The ternary QFR plot shows that the investigated Barakar sandstone samples of Mand basin may be classified as subarkose and sublitharenite type (Fig. 2). 
Table 3: Recalculated framework of the Barakar sandstone of Mand valley basin, Chhattisgarh, India.

\begin{tabular}{|c|c|c|c|c|c|c|c|c|c|c|c|c|c|c|c|c|c|c|c|c|}
\hline \multirow[b]{2}{*}{ S.No. } & \multicolumn{3}{|c|}{ QFR } & \multicolumn{3}{|c|}{ QtFL } & \multicolumn{3}{|c|}{ QmFLt } & \multicolumn{3}{|c|}{ Qp LvLs } & \multicolumn{3}{|c|}{ LsLmLv } & \multicolumn{3}{|c|}{ QmPK } & \multirow[b]{2}{*}{$\mathrm{Qp} / \mathrm{F}+\mathrm{R}$} & \multirow[b]{2}{*}{$\mathrm{Qt} / \mathrm{F}+\mathrm{R}$} \\
\hline & $\mathrm{Q}$ & $\mathrm{F}$ & $\mathrm{R}$ & Qt & F & $\mathrm{L}$ & $\mathrm{Qm}$ & F & Lt & Qp & $\mathrm{Lv}$ & Ls & Ls & $\mathrm{Lm}$ & $\mathrm{Lv}$ & $\mathrm{Qm}$ & $\mathrm{P}$ & $\mathrm{K}$ & & \\
\hline BK-8 & 84.4 & 13.6 & 2.0 & 84.4 & 13.6 & 2.0 & 65.4 & 13.6 & 21.0 & 95.1 & 0.0 & 4.9 & 50.0 & 50.0 & 0.0 & 82.8 & 2.5 & 14.7 & 1.2 & 5.4 \\
\hline BK-9 & 85.0 & 13.9 & 1.1 & 85.0 & 13.9 & 1.1 & 77.8 & 13.9 & 8.3 & 86.7 & 0.0 & 13.3 & 100.0 & 0.0 & 0.0 & 84.8 & 3.6 & 11.5 & 0.5 & 5.7 \\
\hline BK-13 & 79.1 & 7.8 & 13.2 & 91.5 & 7.8 & 0.8 & 85.0 & 8.8 & 6.2 & 85.7 & 0.0 & 14.3 & 100.0 & 0.0 & 0.0 & 90.6 & 5.7 & 3.8 & 0.5 & 4.4 \\
\hline BK-14 & 87.7 & 10.3 & 2.0 & 87.7 & 10.3 & 2.0 & 77.1 & 10.3 & 12.5 & 88.9 & 0.0 & 11.1 & 66.7 & 33.3 & 0.0 & 88.2 & 3.8 & 8.0 & 0.9 & 7.1 \\
\hline BK-16 & 83.0 & 15.5 & 1.5 & 83.0 & 15.5 & 1.5 & 70.5 & 15.5 & 14.0 & 92.6 & 0.0 & 7.4 & 66.7 & 33.3 & 0.0 & 82.0 & 2.9 & 15.1 & 0.7 & 4.9 \\
\hline BK-17 & 86.4 & 10.9 & 2.7 & 86.4 & 10.9 & 2.7 & 71.5 & 10.9 & 17.6 & 89.2 & 0.0 & 10.8 & 66.7 & 33.3 & 0.0 & 86.8 & 2.2 & 11.0 & 1.1 & 6.4 \\
\hline BK-18 & 85.5 & 10.0 & 4.5 & 88.1 & 10.0 & 1.9 & 73.9 & 10.2 & 15.9 & 90.5 & 0.0 & 9.5 & 75.0 & 25.0 & 0.0 & 87.8 & 3.5 & 8.7 & 1.1 & 6.1 \\
\hline BK-19 & 85.1 & 11.9 & 3.0 & 86.0 & 11.9 & 2.1 & 71.5 & 12.0 & 16.6 & 90.4 & 0.0 & 9.6 & 71.4 & 28.6 & 0.0 & 85.7 & 6.6 & 7.7 & 1.0 & 5.8 \\
\hline BK-20 & 82.1 & 17.0 & 0.9 & 83.0 & 17.0 & 0.0 & 75.7 & 17.1 & 7.2 & 100.0 & 0.0 & 0.0 & 0.0 & 0.0 & 0.0 & 81.6 & 7.8 & 10.7 & 0.4 & 4.7 \\
\hline BK-25 & 87.5 & 4.9 & 7.6 & 89.6 & 4.9 & 5.6 & 71.6 & 5.0 & 23.4 & 83.3 & 0.0 & 16.7 & 62.5 & 37.5 & 0.0 & 93.5 & 1.9 & 4.6 & 1.7 & 7.2 \\
\hline BK-26 & 84.9 & 6.7 & 8.4 & 88.2 & 6.7 & 5.0 & 84.3 & 7.0 & 8.7 & 50.0 & 0.0 & 50.0 & 66.7 & 33.3 & 0.0 & 92.4 & 4.8 & 2.9 & 0.3 & 5.8 \\
\hline BK-27 & 82.9 & 8.5 & 8.5 & 85.5 & 8.5 & 6.0 & 74.6 & 8.8 & 16.7 & 70.6 & 0.0 & 29.4 & 71.4 & 28.6 & 0.0 & 89.5 & 6.3 & 4.2 & 0.7 & 5.0 \\
\hline BK-29 & 89.4 & 6.1 & 4.5 & 89.4 & 6.1 & 4.5 & 83.3 & 6.1 & 10.6 & 66.7 & 0.0 & 33.3 & 66.7 & 33.3 & 0.0 & 93.2 & 0.0 & 6.8 & 0.6 & 8.4 \\
\hline BK-35 & 87.0 & 11.5 & 1.5 & 87.0 & 11.5 & 1.5 & 81.2 & 11.5 & 7.3 & 84.8 & 0.0 & 15.2 & 71.4 & 28.6 & 0.0 & 87.6 & 3.8 & 8.6 & 0.5 & 6.7 \\
\hline BK-36 & 82.4 & 11.9 & 5.7 & 85.5 & 11.9 & 2.5 & 76.6 & 12.3 & 11.0 & 76.5 & 0.0 & 23.5 & 100.0 & 0.0 & 0.0 & 86.1 & 5.8 & 8.0 & 0.6 & 4.9 \\
\hline BK-38 & 86.2 & 4.7 & 9.1 & 92.5 & 4.7 & 2.8 & 47.9 & 5.0 & 47.1 & 95.5 & 0.0 & 4.5 & 71.4 & 28.6 & 0.0 & 90.5 & 4.0 & 5.6 & 5.5 & 6.7 \\
\hline BK-40 & 90.2 & 6.2 & 3.6 & 92.9 & 6.2 & 0.9 & 70.8 & 6.4 & 22.8 & 98.0 & 0.0 & 2.0 & 50.0 & 50.0 & 0.0 & 91.7 & 3.0 & 5.3 & 3.0 & 9.5 \\
\hline BK-42 & 93.5 & 3.6 & 2.9 & 93.5 & 3.6 & 2.9 & 85.6 & 3.6 & 10.8 & 78.6 & 0.0 & 21.4 & 75.0 & 25.0 & 0.0 & 96.0 & 3.2 & 0.8 & 1.2 & 14.4 \\
\hline BK-44 & 85.0 & 12.4 & 2.6 & 85.0 & 12.4 & 2.6 & 72.6 & 12.4 & 15.0 & 87.9 & 0.0 & 12.1 & 66.7 & 33.3 & 0.0 & 85.4 & 8.0 & 6.5 & 0.8 & 5.7 \\
\hline BK-45 & 91.6 & 6.2 & 2.2 & 92.4 & 6.2 & 1.3 & 70.0 & 6.3 & 23.8 & 94.3 & 0.0 & 5.7 & 100.0 & 0.0 & 0.0 & 91.8 & 4.1 & 4.1 & 2.9 & 10.9 \\
\hline BK-46 & 89.1 & 9.2 & 1.6 & 89.1 & 9.2 & 1.6 & 81.4 & 9.2 & 9.4 & 88.4 & 0.0 & 11.6 & 62.5 & 37.5 & 0.0 & 89.8 & 4.3 & 5.9 & 0.7 & 8.2 \\
\hline BK-47 & 85.9 & 8.0 & 6.2 & 90.2 & 8.0 & 1.8 & 77.3 & 8.3 & 14.4 & 94.3 & 0.0 & 5.7 & 40.0 & 60.0 & 0.0 & 90.3 & 4.4 & 5.3 & 1.2 & 6.4 \\
\hline BK-49 & 88.1 & 9.3 & 2.7 & 88.1 & 9.3 & 2.7 & 75.2 & 9.3 & 15.5 & 87.9 & 0.0 & 12.1 & 66.7 & 33.3 & 0.0 & 89.0 & 3.7 & 7.3 & 1.1 & 7.4 \\
\hline BK-54 & 86.7 & 9.4 & 3.9 & 87.8 & 9.4 & 2.8 & 82.6 & 9.6 & 7.9 & 75.0 & 0.0 & 25.0 & 60.0 & 40.0 & 0.0 & 89.6 & 7.9 & 2.4 & 0.4 & 6.6 \\
\hline BK-57 & 80.1 & 12.0 & 7.8 & 88.1 & 8.3 & 3.6 & 76.1 & 12.6 & 11.3 & 85.7 & 0.0 & 14.3 & 66.7 & 33.3 & 0.0 & 85.8 & 4.3 & 9.9 & 0.5 & 4.2 \\
\hline BK-58 & 86.0 & 11.7 & 2.3 & 87.0 & 11.7 & 1.3 & 77.3 & 11.8 & 10.9 & 90.6 & 0.0 & 9.4 & 75.0 & 25.0 & 0.0 & 86.7 & 0.7 & 12.5 & 0.7 & 6.2 \\
\hline BK-59 & 83.2 & 14.5 & 2.2 & 83.2 & 14.5 & 2.2 & 69.8 & 14.5 & 15.6 & 92.3 & 0.0 & 7.7 & 50.0 & 50.0 & 0.0 & 82.8 & 6.6 & 10.6 & 0.8 & 5.0 \\
\hline BK-60 & 83.2 & 13.7 & 3.0 & 85.1 & 13.7 & 1.2 & 77.3 & 14.0 & 8.7 & 85.7 & 0.0 & 14.3 & 100.0 & 0.0 & 0.0 & 84.7 & 8.2 & 7.1 & 0.5 & 5.1 \\
\hline BK-61 & 87.9 & 8.4 & 3.7 & 89.7 & 8.4 & 1.8 & 85.1 & 8.6 & 6.3 & 75.0 & 0.0 & 25.0 & 80.0 & 20.0 & 0.0 & 90.8 & 3.2 & 6.0 & 0.4 & 7.4 \\
\hline BK-63 & 83.0 & 14.9 & 2.1 & 83.0 & 14.9 & 2.1 & 73.4 & 14.9 & 11.7 & 85.7 & 0.0 & 14.3 & 75.0 & 25.0 & 0.0 & 83.1 & 9.6 & 7.2 & 0.6 & 4.9 \\
\hline
\end{tabular}

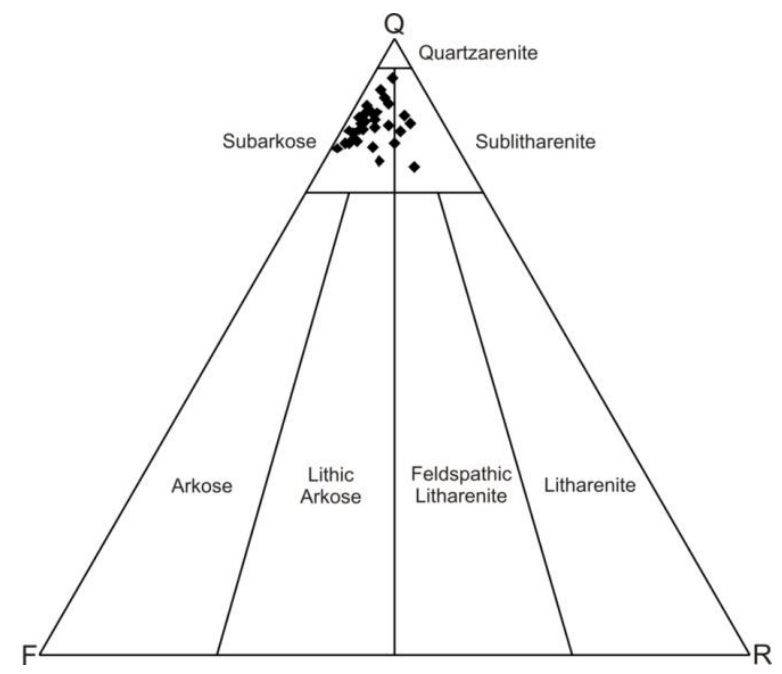

Fig. 2: Classification of Barakar Sandstones of Mand Valley Basin, Raigarh District, Chhattisgarh (after Folk ${ }^{[10]}$ )

\subsection{Geochemistry}

Major element geochemistry gives an idea about the provenance type as well as weathering conditions which in turn are controlled by the tectonic setting of the basin. Major oxides compositions (wt \%) of the Barakar sandstone Mand valley basin are presented in Table 4. The geochemical studies reveal that these Barakar sandstones have high $\mathrm{SiO}_{2}$ contents between 79 to 96 wt. percent. High $\mathrm{SiO}_{2}$ contents reflect quartz-rich nature of these studied sandstones and high $\mathrm{SiO}_{2} / \mathrm{Al}_{2} \mathrm{O}_{3}$ ratio $>10$ (Chemical maturity index, average 13.69) [13], indicate high chemical maturity of the investigated samples. The studied sandstone samples have low $\mathrm{CaO}$ (average $0.241 \mathrm{wt} \%$ ) and relatively high $\mathrm{K}_{2} \mathrm{O}$ (average $2.778 \mathrm{wt}$ $\%)$. Depletion of $\mathrm{Na}_{2} \mathrm{O}\left(<1\right.$ wt \%) and relative enrichment of $\mathrm{K}_{2} \mathrm{O}$ content in Barakar sandstones and the significantly higher $\mathrm{K}_{2} \mathrm{O} / \mathrm{Na}_{2} \mathrm{O}$ ratios (18.13- 33.07) may be due to significantly higher concentration of $\mathrm{K}$-feldspar. $\mathrm{K}_{2} \mathrm{O}$ and $\mathrm{Na}_{2} \mathrm{O}$ contents and their ratios $\left(\mathrm{K}_{2} \mathrm{O} / \mathrm{Na}_{2} \mathrm{O}>1\right)$ are also consistent with the petrographic observations, which shows $\mathrm{K}$-feldspar dominates over plagioclase feldspar. Sandstone rich in quartz ( $>65 \%$ quartz, average $89 \% \mathrm{SiO}_{2}$ and $\left.\mathrm{K}_{2} \mathrm{O} / \mathrm{Na}_{2} \mathrm{O}>1\right)$ are typically associated with passive continental margins [14]. $\mathrm{Al}_{2} \mathrm{O}_{3} / \mathrm{TiO}_{2}$ ratios in clastic rocks are essentially used to infer 
source rock composition because $\mathrm{Al}_{2} \mathrm{O}_{3} / \mathrm{TiO}_{2}$ ratio ranges from 3 to 8 for mafic igneous rocks, from 8 to 21 for intermediate rocks and from 21 to 70 for felsic igneous rocks [15]. $\mathrm{Al}_{2} \mathrm{O}_{3} / \mathrm{TiO}_{2}$ ratios in studied samples suggest felsic igneous rocks as a source rock of Barakar sandstone.

Table 4: Major Oxides Compositions (Wt. \%) of Analyzed Barakar Sandstones of Mand Valley Basin

\begin{tabular}{|c|c|c|c|c|c|c|c|c|c|c|c|c|}
\hline S. No. & $\mathrm{BK} 2$ & BK4 & BK8 & BK17 & BK20 & BK25 & BK35 & BK42 & BK45 & BK57 & BK59 & BK63 \\
\hline $\mathrm{SiO}_{2}$ & 86.32 & 90.38 & 85.72 & 86.36 & 79.50 & 88.60 & 94.11 & 95.76 & 90.68 & 84.01 & 89.75 & 89.40 \\
\hline $\mathrm{Al}_{2} \mathrm{O}_{3}$ & 9.07 & 6.62 & 8.44 & 9.12 & 10.88 & 5.32 & 5.15 & 3.57 & 5.15 & 8.23 & 7.19 & 7.39 \\
\hline $\mathrm{TiO}_{2}$ & 0.12 & 0.12 & 0.13 & 0.27 & 0.63 & 0.20 & 0.16 & 0.10 & 0.18 & 0.29 & 0.12 & 0.25 \\
\hline $\mathrm{Fe}_{2} \mathrm{O}_{3}$ & 0.62 & 0.39 & 3.69 & 1.28 & 2.81 & 4.24 & 0.27 & 0.15 & 0.63 & 0.91 & 0.45 & 1.66 \\
\hline $\mathrm{MnO}$ & 0.02 & 0.00 & 0.02 & 0.02 & 0.12 & 0.07 & 0.00 & 0.00 & 0.00 & 0.01 & 0.00 & 0.03 \\
\hline $\mathrm{MgO}$ & 0.51 & 0.09 & 0.48 & 0.29 & 0.81 & 0.16 & 0.05 & 0.05 & 0.06 & 0.05 & 0.15 & 0.19 \\
\hline $\mathrm{CaO}$ & 0.39 & 0.10 & 0.10 & 0.12 & 0.18 & 0.11 & 0.08 & 0.13 & 0.09 & 0.10 & 0.10 & 0.10 \\
\hline $\mathrm{Na}_{2} \mathrm{O}$ & 0.21 & 0.20 & 0.11 & 0.15 & 0.16 & 0.11 & 0.05 & 0.05 & 0.05 & 0.18 & 0.12 & 0.10 \\
\hline $\mathrm{K}_{2} \mathrm{O}$ & 3.83 & 3.86 & 2.71 & 3.18 & 3.34 & 2.14 & 1.37 & 1.69 & 1.52 & 3.71 & 3.38 & 2.61 \\
\hline $\mathrm{P}_{2} \mathrm{O}_{5}$ & 0.05 & 0.04 & 0.05 & 0.05 & 0.07 & 0.05 & 0.03 & 0.06 & 0.04 & 0.06 & 0.04 & 0.03 \\
\hline LOI & & & & & 1.42 & & & & 1.43 & 1.58 & & \\
\hline Total & 101.14 & 101.80 & 101.45 & 100.85 & 99.92 & 100.98 & 101.27 & 101.55 & 99.82 & 99.13 & 101.30 & 101.74 \\
\hline CIA & 63.56 & 58.56 & 71.87 & 69.93 & 72.12 & 66.48 & 75.04 & 62.38 & 73.20 & 64.71 & 64.09 & 70.05 \\
\hline CIW & 89.53 & 92.97 & 95.85 & 95.04 & 94.85 & 93.49 & 95.72 & 91.77 & 95.59 & 94.55 & 95.03 & 95.65 \\
\hline PIA & 82.29 & 82.95 & 93.77 & 92.27 & 92.48 & 89.04 & 94.10 & 84.43 & 93.64 & 89.89 & 90.39 & 93.14 \\
\hline $\mathrm{SiO}_{2} / \mathrm{Al}_{2} \mathrm{O}_{3}$ & 9.51 & 13.65 & 10.16 & 9.47 & 7.31 & 16.65 & 18.28 & 26.86 & 17.62 & 10.21 & 12.48 & 12.10 \\
\hline $\mathrm{K}_{2} \mathrm{O} / \mathrm{Na}_{2} \mathrm{O}$ & 18.13 & 19.82 & 25.36 & 20.93 & 20.88 & 19.79 & 29.13 & 31.91 & 33.07 & 20.38 & 28.86 & 27.18 \\
\hline $\mathrm{Al}_{2} \mathrm{O}_{3} / \mathrm{TiO}_{2}$ & 74.38 & 54.70 & 66.43 & 33.77 & 17.22 & 27.29 & 32.38 & 37.14 & 28.75 & 28.87 & 58.49 & 29.92 \\
\hline
\end{tabular}

Pettijohn et al. [16] and Herron [17] proposed a diagram to classify the sedimentary rocks on the basis of major oxides. Based on the geochemical classification diagram of Pettijohn et al. [16], the analyzed samples of Barakar Formation of Mand basin are classified as arkose, subarkose and sub-litharenite (Fig. 3 A). It has also been noticed that all the Barakar sandstones are not plotted in the typical fields but near the $\log \mathrm{Na}_{2} \mathrm{O} / \mathrm{K}_{2} \mathrm{O}$ line (below -1.0 line), indicating that these sandstones are affected by a relative $\mathrm{K}$ enrichment or $\mathrm{Na}$ removal. In the geochemical classification diagram of Herron [16] the analyzed Barakar sandstones plot in the subarkose and arkose fields, except for one sample that fall in the litharenite and sub-litharenite area (Fig. $3 \mathrm{~B}$ ). Binary variation diagrams of $\mathrm{SiO}_{2}$ versus $\mathrm{Al}_{2} \mathrm{O}_{3}, \mathrm{TiO}_{2}, \mathrm{Fe}_{2} \mathrm{O}_{3}, \mathrm{MgO}$, $\mathrm{CaO}$, and $\mathrm{K}_{2} \mathrm{O}$ of all the analyzed samples display similar negative linear trends (Fig. 4). While binary variation diagrams of $\mathrm{Al}_{2} \mathrm{O}_{3}$ versus $\mathrm{TiO}_{2}, \mathrm{Na}_{2} \mathrm{O}, \mathrm{K}_{2} \mathrm{O}, \mathrm{Fe}_{2} \mathrm{O}_{3}, \mathrm{MgO}$, and $\mathrm{CaO}$ of all the analyzed samples display similar positive linear trends (Fig. 5).
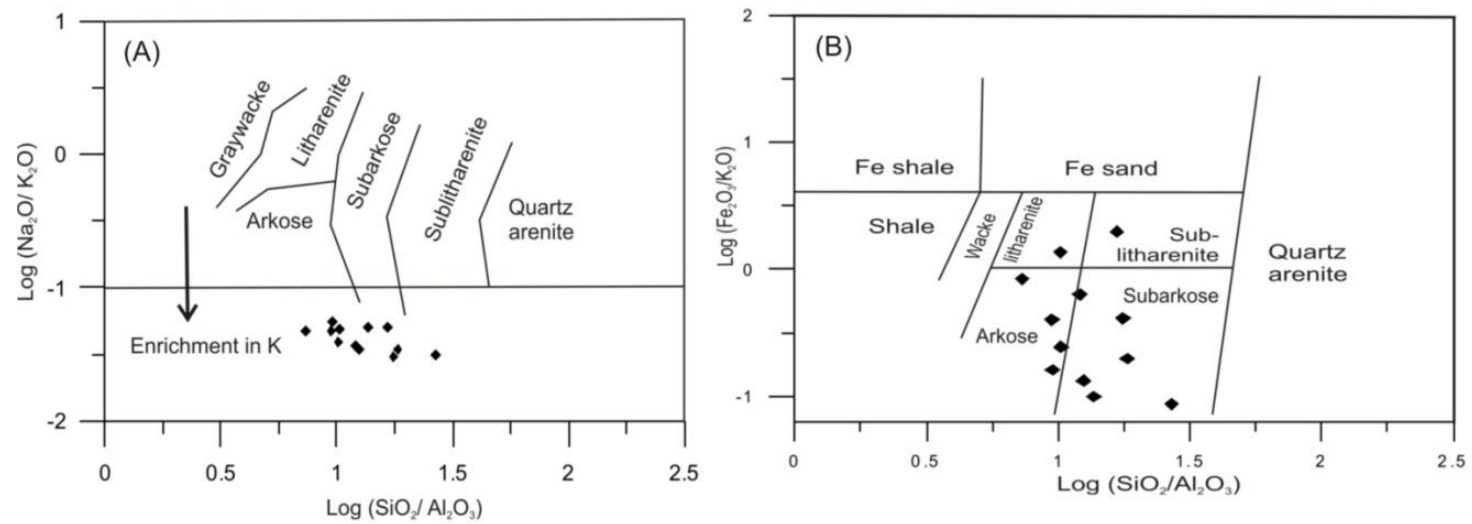

Fig. 3: Geochemical Classification of Sandstone Samples of Barakar Formation Based on (A) the $\log \left(\mathrm{SiO}_{2} / \mathrm{Al}_{2} \mathrm{O}_{3}\right)-\mathrm{Log}\left(\mathrm{Na}_{2} \mathrm{O} / \mathrm{K}_{2} \mathrm{O}\right)$ Diagram of Pettijohn et al. [16] and (B) the $\mathrm{Log}\left(\mathrm{SiO}_{2} / \mathrm{Al}_{2} \mathrm{O}_{3}\right)-\log \left(\mathrm{Fe}_{2} \mathrm{O}_{3} / \mathrm{K}_{2} \mathrm{O}\right)$ Diagram of Herron [17]. 

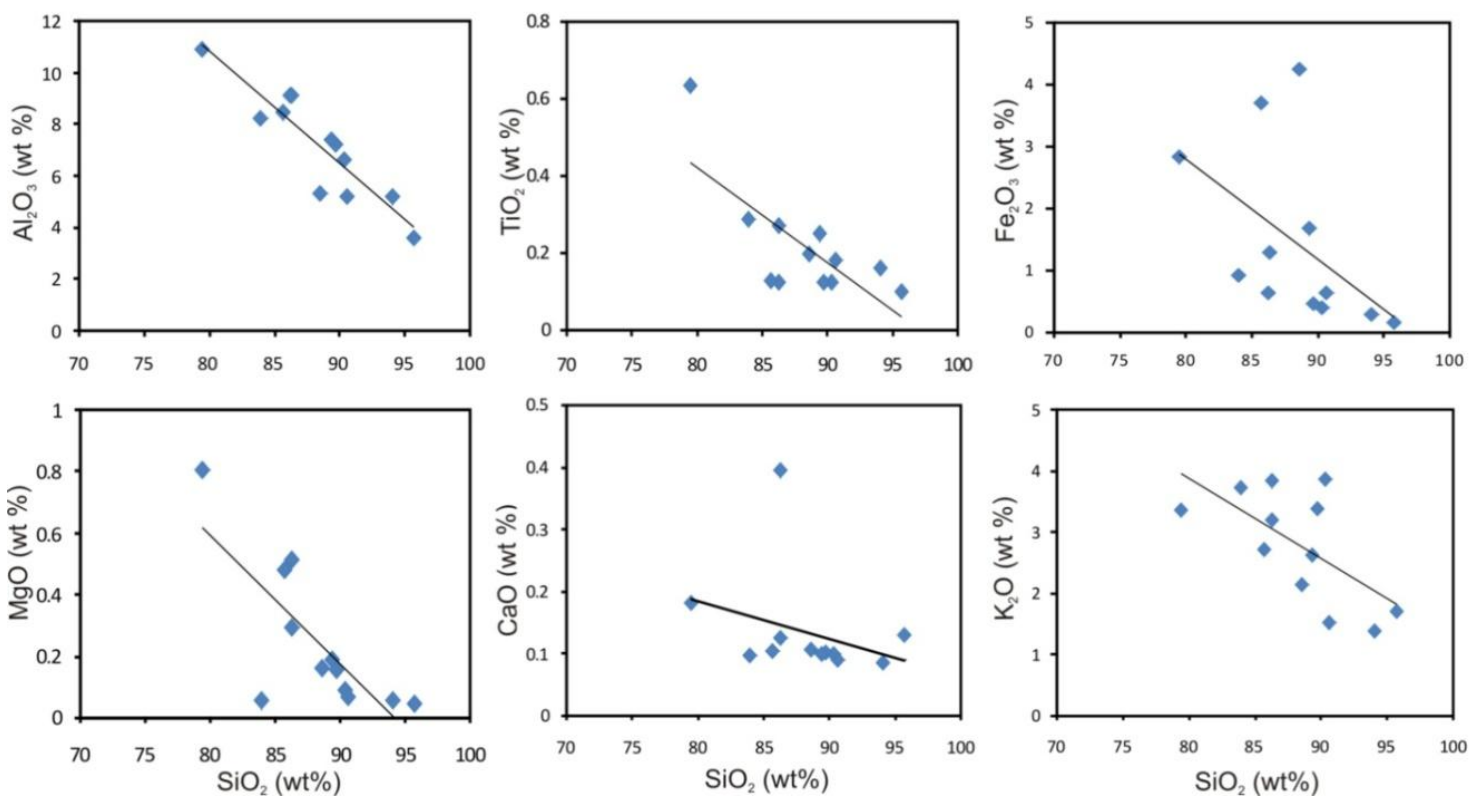

Fig. 4: Binary Variation Diagrams of Barakar Sandstone Major Oxides against $\mathrm{SiO}_{2}$
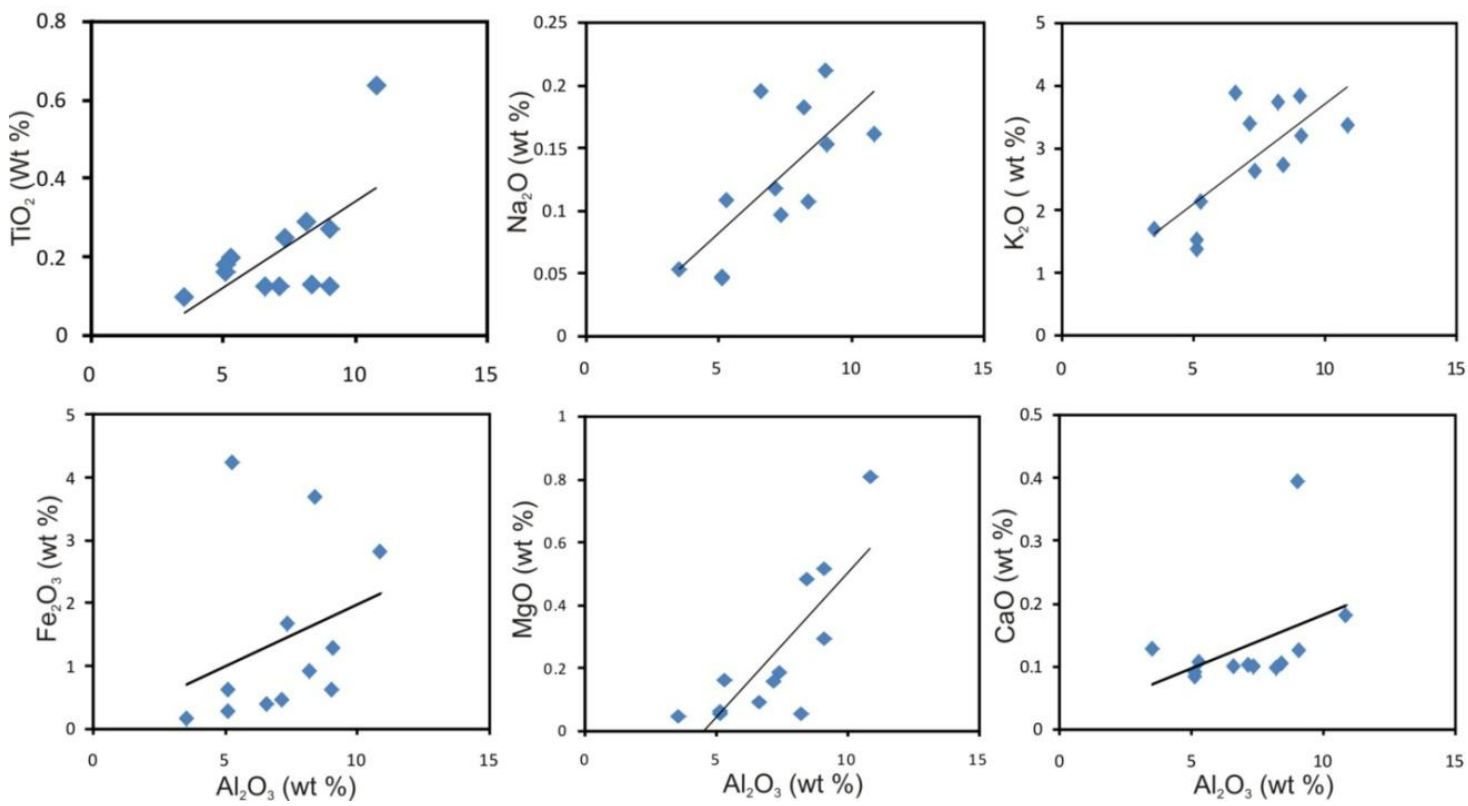

Fig. 5: Binary Variation Diagrams of Barakar Sandstone Major Oxides against $\mathrm{Al}_{2} \mathrm{O}_{3}$

\section{Discussion}

\subsection{Paleoclimate and chemical maturity}

An invariant $\log / \log$ plot between $\mathrm{Qp} / \mathrm{F}+\mathrm{R}$ and $\mathrm{Qm} / \mathrm{F}+\mathrm{R}$ of the climate discrimination diagram [12], suggests prevalence of humid climate during the sedimentation of Barakar sandstones (Fig. $6 \mathrm{~A}$ ). In the Q-F-R ternary diagram [11], these sandstones plot in the field of metamorphic source area with humid climatic condition (Fig. 6 B). A bivariant plot of $\mathrm{SiO}_{2}$ versus $\mathrm{Al}_{2} \mathrm{O}_{3}+\mathrm{K}_{2} \mathrm{O}+\mathrm{Na}_{2} \mathrm{O}$ proposed by Suttner and Dutta [16] was used in order to identify the maturity of the Barakar sandstones as a function of climate. This plot suggests that all but one the samples, which fall in the arid climate field, have been derived from a provenance having humid climatic condition (Fig. $6 \mathrm{C}$ ). 


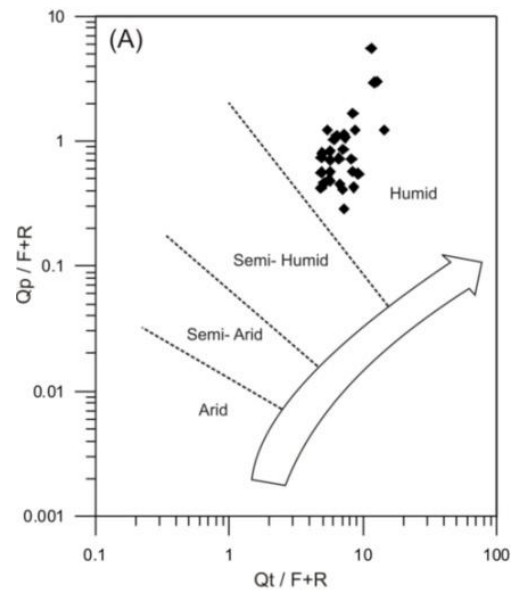

(B)

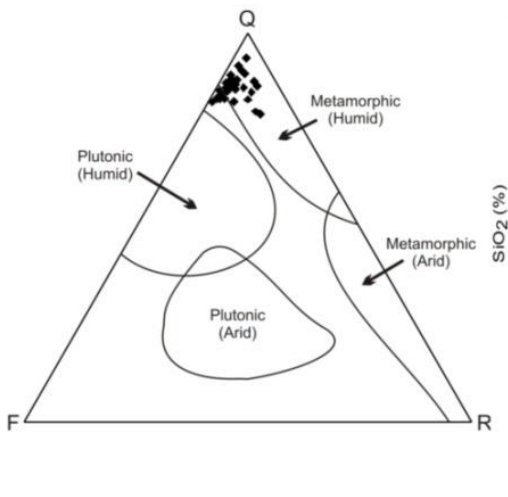

(C)

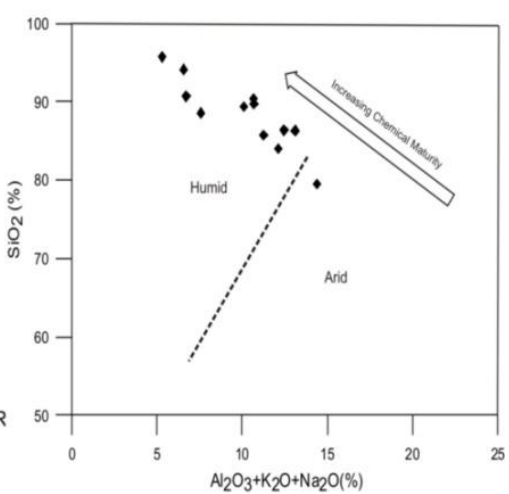

Fig. 6: (A) An Invariant Log/Log Plot Between $Q p / F+R$ And $Q m / F+R$ (After Suttner And Dutta ${ }^{[12]}$ ), (B) QFR Ternary Plot (After Suttner et al. ${ }^{[1]}$ ) as a Function Of Climate (C) Bivariant Plot Of $\mathrm{SiO}_{2}$ Versus $\mathrm{Al}_{2} \mathrm{O}_{3}+\mathrm{K}_{2} \mathrm{O}+\mathrm{Na}_{2} \mathrm{O}$ (After Suttner And Dutta ${ }^{[12]}$ ) For Barakar Sandstones.

\subsection{Provenance and tectonic setting}

The recalculated petrographic data is plotted in the ternary diagrams [1], [2], [3] to decipher the tectonic setting of Barakar sedimentation in Mand valley basin, Raigarh district, Chhattisgarh. The QtFL and QmFLt diagrams [2] show that these Barakar sandstones were derived from craton interior and recycled orogenic provenance (Fig. 7 A and 7 B).
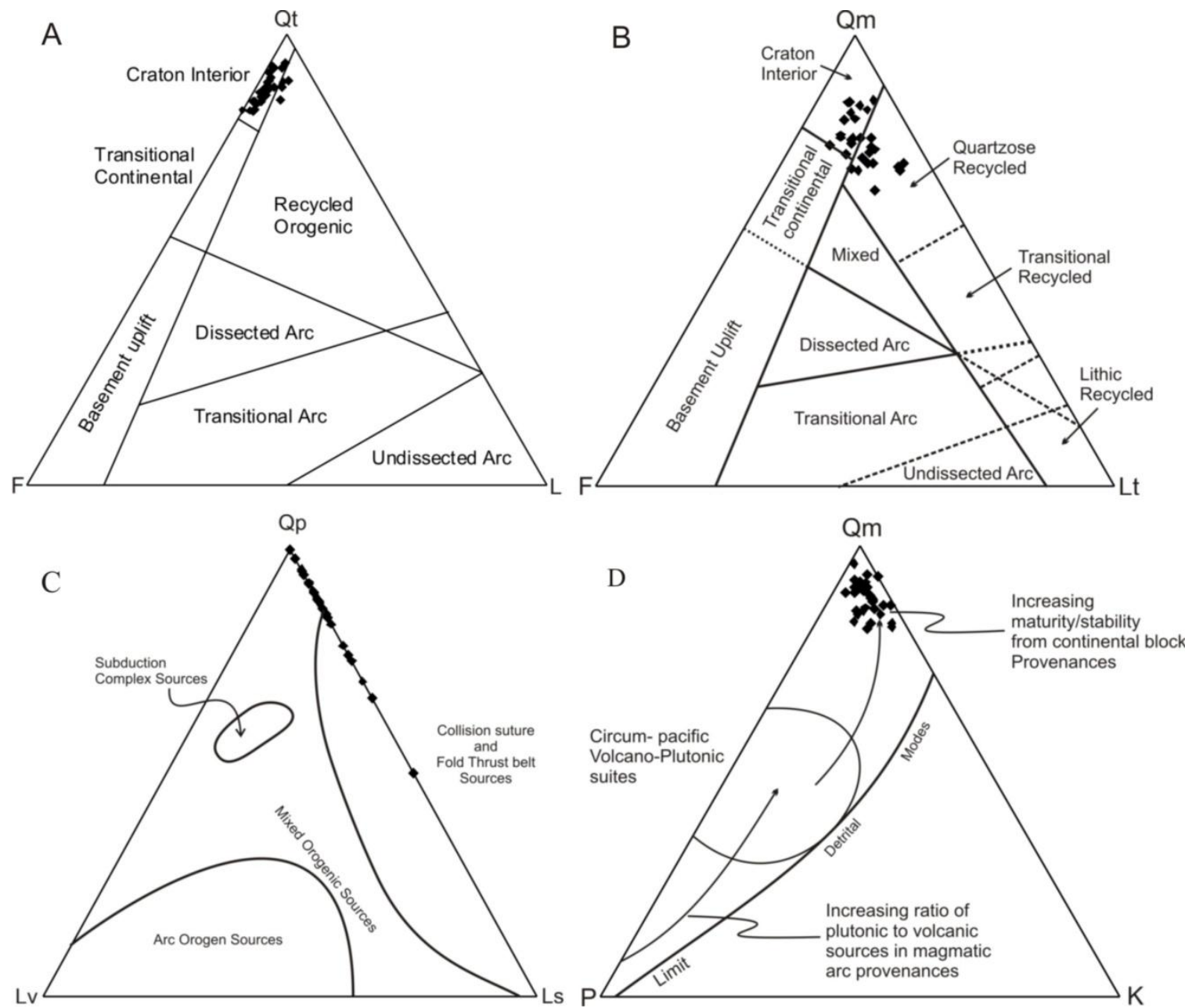

Fig 7: (A) QtFL and (B) QmFLt Ternary Provenance Discrimination Diagram For Barakar Sandstone after Dickinson et al. [2], (C) QpLvLs and (D) QmPK Ternary Provenance Discrimination Diagram for Barakar Sandstone after Dickinson, [3].

As pointed out by Dickinson et al, [2], sandstones plotted in craton interior provenance are mature sandstones derived from relatively low-lying granitoid and gneissic sources, supplemented by recycled sands from associated platform or passive margin basins. Presence of greater amount of alkali feldspar than plagioclase in studied samples supports a 
granitic source for these Barakar sandstones. Samples plotted in the recycled orogenic provenance field are commonly derived from sedimentary and meta-sedimentary sources, which were originally deposited in passive continental margins [1], [2], [3], [18]. The QmPK ternary diagram [3] suggests that these Barakar clastics were derived from the continental block provenance (Fig. 7 C). In the QpLvLs ternary diagram [3], the studied Barakar sandstone specimens fall in the field of the collision suture and fold thrust belt source (Fig. 7 D).

Various workers [19], [20], [21] proposed tectonic setting discrimination fields for sedimentary rocks to identify the tectonic setting of unknown basins. The $\mathrm{K}_{2} \mathrm{O} / \mathrm{Na}_{2} \mathrm{O}$ versus $\mathrm{SiO}_{2}$ tectonic setting discrimination diagram [20] indicates the passive margin field for the Barakar formation of the investigated area (Fig. 8 A). Quartz-rich sediments derived from plate interiors or stable continental areas and deposited in intra-cratonic basins or on passive continental margins [20]. High value of $\mathrm{SiO}_{2}, \mathrm{~K}_{2} \mathrm{O} / \mathrm{Na}_{2} \mathrm{O}$, and also $\mathrm{K}$ - feldspar rather than plagioclase, demonstrate felsic plutonic source for the studied sand samples. Discrimination functions diagram based on major element data describe four provenances viz mafic igneous, intermediate, felsic and quartzose recycled [21]. In This diagram, the Barakar sandstone occupy recycled sedimentary provenance field, suggesting that these sandstones were derived from a craton interior or recycled orogenic provenance (Fig. 8 B).
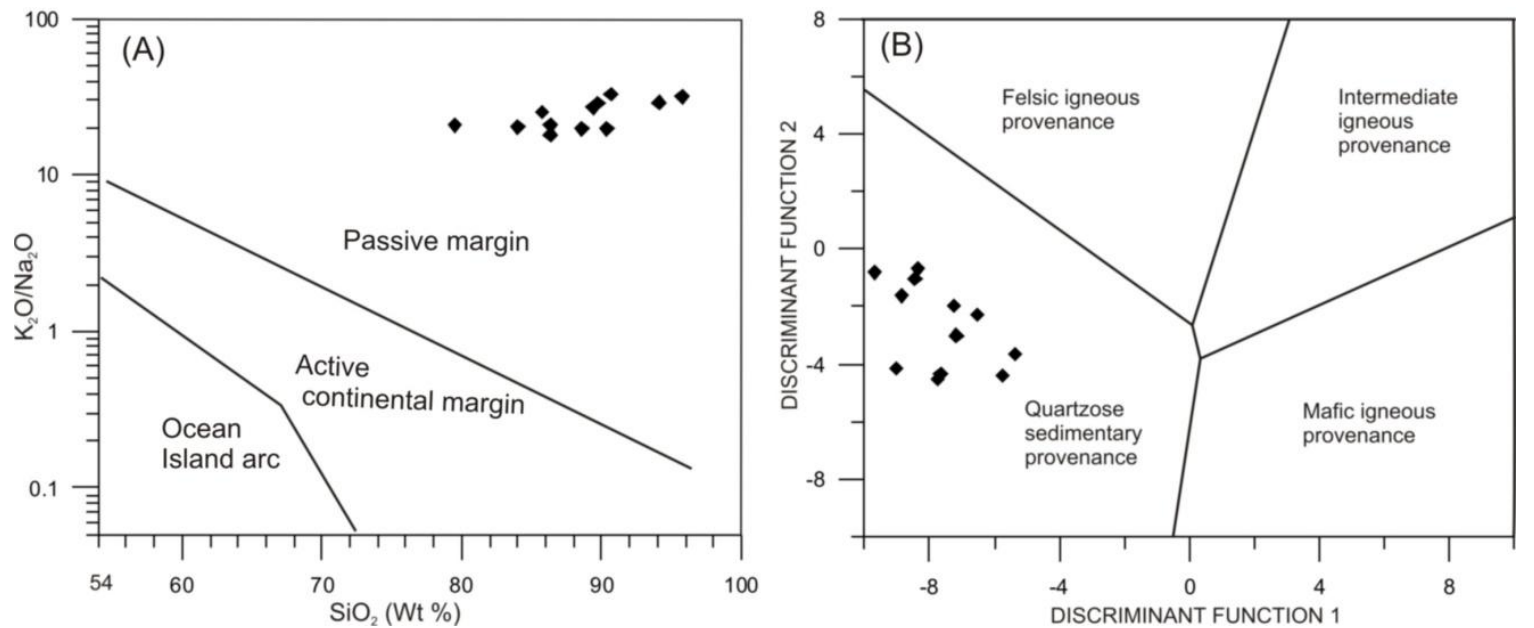

Fig. 8: (A) $\mathrm{K}_{2} \mathrm{O} / \mathrm{Na}_{2} \mathrm{O}$ versus $\mathrm{SiO}_{2}$ Plot of Barakar Sandstone with Discrimination Fields after Roser and Korsch [21]; (B) Discriminant Diagram for Barakar Sandstone after Roser and Korsch [21].

\subsection{Source area weathering}

The intensity and duration of weathering in clastic sediments can be evaluated by examining the relationships among alkali and alkaline earth elements [22, 23]. The Chemical Index of Alteration (CIA) defined by Nesbitt and Young [24] is used to quantify the degree of source area weathering. The formula used to calculate the Chemical Index of Alteration: $\mathrm{CIA}=\left[\mathrm{Al}_{2} \mathrm{O}_{3} /\left(\mathrm{Al}_{2} \mathrm{O}_{3}+\mathrm{CaO} *+\mathrm{Na}_{2} \mathrm{O}+\mathrm{K}_{2} \mathrm{O}\right)\right] * 100$, where the oxides are expressed as molar proportions and $\mathrm{CaO}^{*}$ represents the $\mathrm{CaO}$ in silicate fractions only. The CIA values of Barakar sandstones of study area range from 58.56-75.04 (average 67.66) suggests moderate weathering condition. $\mathrm{A} \mathrm{K}_{2} \mathrm{O}$ - free indices, Chemical index of weathering (CIW), defined as $\left[\mathrm{Al}_{2} \mathrm{O}_{3} /\left(\mathrm{Al}_{2} \mathrm{O}_{3}+\mathrm{CaO} *+\mathrm{Na}_{2} \mathrm{O}\right)\right]^{*} 100$ by Harnois [25] is measured. The CIW range 89.53-95.85 (average 94.17) suggests intense weathering environment for studied sandstone samples. The degree of the chemical weathering [26] can also be estimated using the Plagioclase Index of Alteration (PIA); in molecular proportions: $\mathrm{PIA}=\left[\left(\mathrm{Al}_{2} \mathrm{O}_{3}-\mathrm{K}_{2} \mathrm{O}\right) /\left(\mathrm{Al}_{2} \mathrm{O}_{3}+\mathrm{CaO} *+\mathrm{Na}_{2} \mathrm{O}-\mathrm{K}_{2} \mathrm{O}\right)\right] \times 100$, where $\mathrm{CaO} *$ is the $\mathrm{CaO}$ residing only in the silicate fraction. Barakar sandstone of study area show very high PIA values (82.29 to 94.10, average $=89.86$ ) suggesting intense plagioclase weathering in source area and indicating that most of the plagioclase has been converted to clay minerals. The A-CN-K $\left(\mathrm{Al}_{2} \mathrm{O}_{3}-\mathrm{CaO}+\mathrm{Na}_{2} \mathrm{O}-\mathrm{K}_{2} \mathrm{O}\right)$ Ternary diagram [27] shows the studied sandstone cluster near the A-K edge, along muscovite to illite composition indicating moderate weathering of the source rocks (Fig. 9). An estimation of source rock compositions can be made by the backward projection of the samples to a point on the feldspar line (Plagioclase - K-feldspar). The intersection point provides an approximate ratio of plagioclase to Kfeldspar in the source rock. In this diagram the weathering trend of sandstone suggests average granite as source rock for Barakar sandstones of Mand valley basin, Raigarh district, Chhattisgarh. 


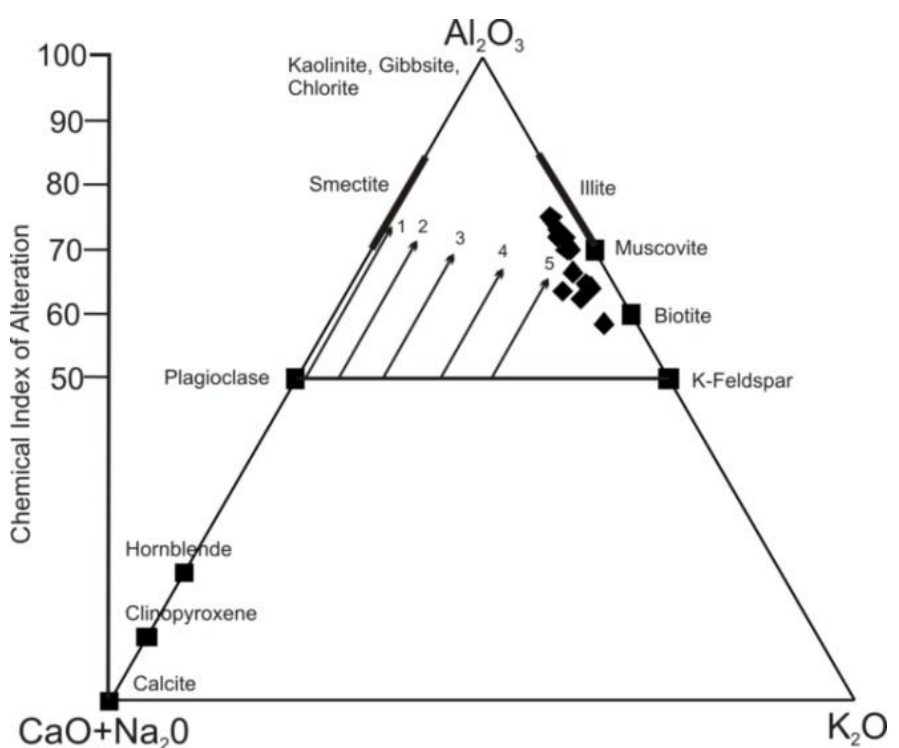

Fig. 9: A-CN-K $\left(\mathrm{Al}_{2} \mathrm{O}_{3}-\mathrm{CaO}+\mathrm{Na}_{2} \mathrm{O}-\mathrm{K}_{2} \mathrm{O}\right)$ Ternary Diagram [27] For the Barakar Sandstones of Mand Valley Basin, Chhattisgarh. The Arrows 1-5 Denotes the Weathering Trends of Gabbro, Tonalite, Granodiorite, Adamellite and Granite Respectively.

\section{Conclusion}

The Barakar Formation in Mand valley basin, Raigarh district, Chhattisgarh, mainly consists of sandstones, shale and coal deposited under a fluvial environment. Based on the petrographic results, these Barakar sandstones are subarkose to sub-litharenite in composition and are derived from craton interior and recycled orogenic provenances. The discrimination plots indicate that studied Barakar sandstones were derived from polycyclic continental sedimentary rocks as well as granitic- gneissic or sedimentary sources and deposited on a passive margin with mature detrital sediments. The large $\mathrm{SiO}_{2}$ contents and large $\mathrm{K}_{2} \mathrm{O} / \mathrm{Na}_{2} \mathrm{O}$ ratios reflect derivation from stable cratonic area or passive continental margin. The A-CN-K ternary diagram suggests a granitic source composition. CIA, CIW and PIA indices values for the Barakar sandstones indicate that these clastics were derived from moderate to relatively high degree of chemically weathered of source rock under humid climatic condition.

\section{Acknowledgement}

The authors are thankful to the Chairperson, Department of Geology, Aligarh Muslim University, Aligarh (India) for providing the necessary facilities. Corresponding author is also grateful to the University Grants Commission (UGC Non-Net fellowship) for financial assistance to carry out this study. And sincere thanks to Prof. M.E.A Mondal for review of this paper. We are indebted to Dr. Abhay V. Mudholkar for his kind co-operation during the geochemical analysis at the National Institute of Oceanography, Goa (India).

\section{References}

[1] Dickinson, W. R. and Suczek, C. A., "Plate Tectonics and Sandstone Compositions", AAPG Bulletin, Vol. 63, (1979), pp. $2164-2182$.

[2] Dickinson, W.R., Beard, L.S., Brakenridge, G.R., Erjavec, J.L., Ferguson, R.C., Inman, K.F., Knepp, R.A., Lindberg, F.A., Ryberg, P.T., "Provenance of North American Phanerozoic sandstone in relation to tectonic setting". Geol. Soc. Am. Bull. Vol. 94, (1983), pp. $222-235$.

[3] Dickinson, W. R., "Interpreting Provenance Relations from Detrital Modes of Sandstones." NATO ASI Series, Series C: Mathematical and Physical Sciences, Vol. 148, (1985), pp. 333-361.

[4] Potter, P.E, "South America and a few grains of sands: Part 1: Beach sands; The Journal of Geology, Vol. 94, No. 3 (1986), pp. 301-319.

[5] Vaidyanadhan, R. and Ramakrishnan, M., Geology of India (Volume 2). Geological Society of India, Bangalore, (2010).

[6] Raja Rao, C.S. (1982) Coalfields of India, Vol. II. Coal Resources of Tamilnadu, Andhra Pradesh, Orissa and Maharashtra. Bulletin of the Geological Survey of India, 45(A), 41-52.

[7] Raja Rao, C.S. “Coalfields of India, Coal Resources of Madhya Pradesh and Jammu \& Kashmir.” Bulletin of the Geological Survey of India, Vol. III. No. 45(A), (1983), pp. 1-20.

[8] Dickinson, W.R., "Interpreting detrital modes of greywacke and arkose. J. Sediment. Petrol. Vol. 40, (1970), pp. 695-707.

[9] Ingersoll, R. V., Fullard, T. F., Ford, R. L., et al., "The Effect of Grain Size on Detrital Modes: A Test of the Gazzi-Dickinson Point Counting Method.” Journal of Sedimentary Petrology, Vol. 54, (1984), pp. 103-116.

[10] Folk, R. L., Petrology of sedimentary rocks. Hemphill Publishing, Austin, Texas, (1980).

[11] Suttner LJ, Basu A, Mack GH, "Climate and the origin of quartz arenites". Journal of Sedimentary Petrology, Vol. 51: (1981), pp. 235-246

[12] Suttner, L. J., Dutta, P. K., “Alluvial Sandstone Composition and Paleoclimate: I, Framework Mineralogy.” Journal of Sedimentary Petrology, Vol. 56, (1986) pp. 329-345. 
[13] Potter, P.E., "Petrology and Chemistry of modern Big River Sand.” Journal of Geology Vo.86, No.4 (1978), pp. 423-449.

[14] Crook, K.A.W., "Lithogenesis and geotectonics: The significance of compositional variation in flysch arenites (graywackes)", The Society of Economic Paleontologists and Mineralogists (SEPM), Special publication 19, (1974), pp. 304-310.

[15] Hayashi, K., Fujisawa, H., Holland, H., Ohmoto, H., "Geochemistry of 1.9 Ga sedimentary rocks from northeastern Labrador, Canada: Geochimica et Cosmochimica Acta, Vol. 61(19), (1997), pp. 4115-4137.

[16] Pettijohn, F.J., Potter, P. E., Siever, R., Sand and Sandstones: Springer-Verlag, New York, (1972)

[17] Herron, M.M., 1988, "Geochemical classification of terrigenous sands and shales from core or log data", Journal of Sedimentary Petrology, 58, 820-829.

[18] Ingersoll, R. V., and Suczek, C. A., "Petrology and provenance of Neogene sand from Nicobar and Bengal fans, DSDP Sites 211 and 218 ". Journal of Sedimentary Petrology, vol. 49 (1979), pp.1217-1228.

[19] Bhatia, M. R., "Plate Tectonics and Geochemical Composition of Sandstones", Journal of Geology, Vol. 91, (1983), pp. $611-627$.

[20] Roser, B. P., Korsch, R. J., "Determination of Tectonic Setting of Sandstone-Mudstone Suites Using SiO 2 Content and K $\mathrm{O}_{2} \mathrm{Na}_{2} \mathrm{O}_{\mathrm{Ratio}}$ Journal of Geology, Vol.94 (1986), pp. 635-650.

[21] Roser, B. P., Korsch, R. J., "Provenance Signatures of Sandstone-Mudstone Suites Determined Using Discriminant Function Analysis of Major-Element Data. Chemical Geology, Vol. 67, (1988), pp. 119-139.

[22] Nesbitt, H.W. \& Young, G.M., "Petrogenesis of sediments in the absence of chemical weathering: effects of abrasion and sorting on bulk composition and mineralogy." Sedimentology, Vol.43, (1996), pp. 341-358.

[23] Nesbitt, H.W., Fedo, C.M. \& Young, G.M., "Quartz and feldspar stability, steady and non-steady state weathering and petrogenesis of siliciclastic sands and muds.” Journal of Geology, Vol.105, (1997). pp. 173-191.

[24] Nesbitt, H. W., Young, G. M., "Early Proterozoic Climates and Plate Motions Inferred from Major Elemental Chemistry of Lutites. Nature, Vol. 299, (1982), pp. 715-717

[25] Harnois, L., “The CIW Index: A New Chemical Index of Weathering.” Sedimentary Geology, Vol. 55, (1988), pp. 319-322.

[26] Fedo, C.M., Nesbitt, H.W and Young, G.M., "Unravelling the effects of potassium metasomatism in sedimentary rocks and paleosols, with implications in weathering conditions and provenance", Geology, Vol. 23, (1995), pp. 921-924.

[27] Nesbitt, H.W and Young, G.M., "Prediction of some weathering trend of plutonic and volcanic rocks based on thermodynamic and kinetic ‘consideration", Geochimica et Cosmochimica Acta, Vol. 48, (1984), pp. 1523-1534. 